\title{
WANA TANI SEBAGAI SALAH SATU METODE DALAM KONSERVASI TANAH DAN AIR
}

\author{
Yohanes Emil Satriawan \\ Dinas Pertanian, Maumere NTT-Flores \\ yon_satria@yahoo.co.id
}

\section{SUMMARY}

\section{Agroforestry as Ones of the Methods in Soil and Water Conservation}

Soil and water is the most important resources. Soil is the main media for people to get basic necessities and doing activities. The negative effect of soil erosion for land productivity is decreasing water reserves, nutrition, organic substances and depth root. Soil erotion was decrease the ability of soil to hold up soft particle and organic subtances carried over.

A way to minimize erotion effect is apply agroforestry system. Agroforestry is sustainable conservation system for crop, trees and breed management based on sosial economic and ecological pattern.

\section{Key Word : Agroforestry, Conservation, Water and Soil}

\section{PENDAHULUAN}

Tanah dan air merupakan sumber daya yang paling fundamental. Tanah merupakan media utama bagi manusia untuk mendapatkan bahan pangan, sandang, papan, tambang dan tempat dilaksanakannya berbagai aktivitas.

Kepemilikan lahan perkapita semakin menurun, jika penurunan ini diikuti dengan penurunan tingkat produktivitas lahan akibat degradasi, maka manusia akan mengalami kesulitan dalam pemenuhan kebutuhan bahan pangan maupun tempat tinggal. Degradasi tersebut dapat diakibatkan oleh adanya erosi dan salinasi atau penggaraman pada tingkat yang mengkha wati rkan.

Erosi tanah berpengaruh negative terhadap produktivitas lahan melalui pengurangan ketersediaan air, nutrisi, bahan organic dan menghambat kedalaman perakaran (Owoputi and Stolte, 1995). Dilaporkan akibat erosi tanah, laju infiltrasi kedalaman tanah mengalami penurunan sampai 90\% (Pimmentel, 1993). Erosi tanah mengurangi kemampuan tanah menahan air karena partikel - partikel lembut dan bahan organik dalam tanah terangkut. Selain mengurangi produktivitas lahan dimana erosi terjadi, erosi tanah juga menyebabkan masalah lingkungan yang serius terutama di daerah hilir dimana sedimen hasil erosi mengendap dan mendangkalkan sungai sungai, danau, waduk sehingga mengurangi kemampuannya untuk irigasi, pembangkit listrik, perikanan, navigasi dan rekreasi.

Saat ini telah terjadi penurunan kualitas kedua sumber daya tersebut, sehingga tanpa adanya upaya - upaya konservasi yang sungguh - sungguh akan menimbulkan malapetaka yang mengancam kelangsungan hidup manusia. Salah satu upaya konservasi tanah dan air adalah dengan menerapkan system wanatani atau biasa disebut dengan agroforestry.

Wanatani merupakan usaha penanaman dan pengelolaan pepohonan bersama dengan tanaman ataupun ternak yang secara ekologis, sosial dan ekonomis dapat berkelanjutan atau dengan kata Iain wanatani adalah penggunaan pepohonan dalam sistem - sistem usaha tani (Gintings, 1997).

Menurut Fitriadi, dkk (1997), beberapa tujuan dari wanatani adalah : meningkatkan produksi atau pendapatan petani, peningkatan pemerataan perolehan manfaat, pengolahan lahan kering secara berkelanjutan. Untuk itu tulisan ini bertujuan agar mengetahui peranan wana tani dalam konservasi tanah dan air serta mengetahui sistem - sistem wanatani yang dikembangkan di seluruh Indonesia sebagai upaya konservasi tanah dan air.

\section{ULASAN}

Dengan terjadinya erosi secara terus menerus mengakibatkan produktifitas tanah menurun. Akibatnya produksi pertanian semakin menurun, dalam hal ini dibutuhkan suatu teknologi yang dapat memenuhi kepentingan dan kelestarian tanah, lingkungan serta kepentingan pangan bagi manusia.

\section{Model Pengembangan Lingkungan}

Model ini merupakan salah satu dari beberapa konsep pengembangan wanatani. Cruz dan Vegara (1987) mengusulkan suatu model yang menunjukkan peran wanatani dalam perlindungan dan rehabilitasi lahan - lahan kritis didaerah pegunungan. 
Sumber daya alam dengan komponen komponennya, air, tanah, hutan dan sumber daya manusia dipengaruhi oleh beberapa faktor lingkungan seperti iklim, sosial ekonomi, politik, budaya dan bio fisik. Sistem - sistem wanatani dikembangkan untuk memanfaatkan faktor - faktor yang berpengaruh tersebut dengan mengelola sumber daya alam secara efektif.

Manlaat dari jasa - jasa yang dapat diperoleh dari sistem - sistem wanatani adalah perlindungan dan rehabilitasi lahan. Aspek perlindungan mencakup pengurangan erosi tanah, tanah longsor, menghambat aliran permukaan, menghambat kehilangan hara dan evaporasi. Rehabilitasi mencakup perbaikan status hara, kadar bahan organik, $\mathrm{pH}$ tanah, struktur tanah, pengendalian hama dan penyakit serta penurunan suhu radiasi matahari. Selain itu manfaat jangka panjang dari wana tani adalah peningkatan produktivitas pertanaman, perbaikan gizi dan kesehatan, perbaikan sosial ekonomi, tata guna lahan yang lebih mantap dan perbaikan konservasi lingkungan. Oleh sebab itu bila dilaksanakan lebih baik sistem - sistem wana tani dapat merupakan alat atau sarana yang efektif untuk merehabilitasi dan mengelola lahan - lahan kriris di daerah dan menggalakkan pembangunan di pedesaan (Cruz dan Vegara, 1987).

\section{Modal Usaha Tani}

Untuk mengembangkan sistem wana tani dapat ditempuh dengan pendekatan usaha tani (farming system) yang disarankan oleh Byerlee dan Collinson (1980 dalam Soegianto, 1991). Dalam usaha tani keputusan petani dalam menerapkan teknologi dipengaruhi oleh kondisi alam dan sosial ekonomi. Lingkungan alam terdiri dari keadaan tanah dan toposirafi seperti tipe tanah, kesuburan tanah, kemiringan lapangan dan elevasi. Kondisi - kondisi biologi berupa hama penyakit, fisiologi tanaman, hewan dan gulma. Kondisi iklim berupa curah hujan dan kelembaban.

Kondidi - kondidi sosial ekonomi dapat bersifat internal dan eksternal. Kondisi iknternal berupa tujuan usaha tani dan kendala sumber daya. Tujuan usaha tani dan kendala sumber daya. Tujuan usaha tani dapat berupa pemenuhan kebutuhan sendiri, peningkatan pendapatan dan meminimalkan resiko. Kondisi ekonomi umum dapat dilihat dari kendala kendala mengenai lahan, tenaga kerja dan modal usaha. Kondisi eksternal terdiri dari pasar yang dipengaruhi oleh kebijaksanaan nasional.

\section{Penggolongan Sistem - sistem Wana Tani}

Fitriadi, dkk (1997) menggolongkan beberapa sistem dalam kegiatan wana tani, antara lain :

1. Berdasarkan komponen - komponennya : sistem ini merupakan gabungan antara pohon, tanaman pangan, padang pengembalaan dan komponen komponen lainnya.

2. Berdasarkan fungsi pepohonan : pepohonan yang digunakan hendaknya mempunyai fungsi terutama untuk produksi maupun untuk konservasi.

3. Berdasarkan lahannya : apakah sistem wana tani bersifat sementara ataukah terbentuk secara tetap.

4. Berdasarkan pola pepohonan : pola pepohonan yang dikelola apakah pola yang teratur ataukah tersebar tidak teratur.

5. Berdasarkan hak kepemilikan : Penerapan wana tani dipengaruhi oleh sistem hak atas tanah dan pepohonan (perseorangan, komunal atau dikuasai oleh Negara) yang berlaku untuk para petani. Hak - hak tersebut mempengaruhi keputusan - keputusan yang diambil oleh petani tentang sistem wana tani yang dapat dimanfaatkan.

\section{Evolusi Wana Tani}

Sistem - sistem wana tani di Asia Tenggara telah berkembang selama berabad - abad menjadi berbagai sistem yang rumit seperti yang dapat kita amati. Pada saat ini, sesuai dengan perubahan keadaan para petani masih meiakukan eksperimen dan memperbaiki sistem - sistem tersebut.

Untuk metnenuhi kebutuhan pangan, pakan ternak, kayu bakar, serat dan uang tunai, para petani memadukan tanaman pangan, pepohonan dan ternak dalam sistem - sistem wana tani mereka. Pemaduan ini telah menghasilkan beranekaragam sistem wana tani tradisional. Kebanyakan sistem tersebut telah sesuai dengan keadaan agroekologis setempat, dengan kebutuhan spesifik para petani akan pangan dan uang tunai dengan konteks sosial dan kebudayaannya serta dengan kebutuhan konservasi.

Masyarakat yang tinggal di daerah - daerah yang masih berhutan atau bahkan masih dikelilingi oleh hutan yang lebat (misalnya dibeberapa daerah di Laos dan Indonesia), mereka biasa bertani dengan cara tebas-bakar atau ladang berpindah dan mengumpulkan berbagai hasil hutan baik untuk keperluannya sendiri maupun untuk dijual.

Pada pertanian menetap, pepohonan telah cukup terpadu dengan sistem - sistem pertanian. Di daerah yang berpenduduk padat sering kali 
pohon lebih dihargai dan diberi harga yang lebih tinggi dari pada di daerah berpenduduk jarang dimana hutan masih banyak. Sistem sistem wana tani, khususnya di daerah berpenduduk padat dan kekurangan kayu bakar, dapat berfungsi sebagai daerah penyangga (buffer zone) yang dapat mengurangi kerusakan hutan.

Pepohonan yang ditanam di Iahan pertanian dan sekitarnya telah dipilih dengan penuh pertimbangan. Jika sistem tersebut berdasarkan pada pohon yang baru akan panen dalam waktu yang lama misalnya kelap, kemiri, karet, jati, pohon buah dan sebagainya, para petani biasa menanamnya secara tumpang sari dan atau memadukannya dengan ternak untuk memperoleh penghasilan yang lebih awal.

Para petani yang tinggal disekitar hutan di daerah - daerah yang padat penduduknya telah menemukan cara untuk memadukan sistem - sistem pertanian mereka dengan hutan yang ada, misalnya dengan menggembalakan ternak mereka di dalam hutan (atau mengambil pakan dari hutan), atau membuka kebun kebun di hutan untuk mencukupi kebutuhan sub sistem atau kebutuhan terhadap uang.

\section{Penyesuaian Teknologi Tradisional Terhadap Teknologi yang Diperkenalkan Suatu sistem wanatani dapat} mempergunakan : teknologi tradisional yang ada dan telah dikenal oleh para petani, teknologi yang telah diubah atau diperbaiki oleh para petani atau oleh orang luar, cara - cara yang diperkenalkan oleh para penyuluh atau peneliti dari luar.

Teknologi tradisional yang telah ada seharusnya menjadi dasar dalam merancang tindakan - tindakan pengembangan system wana tani. Tetapi kenyataannya adalah bahwa banyak proyek yang telah mengandalkan model - model wana tani dengan spesies - spesies eksotik dengan teknologi - teknologi yang diperkenalkan dari luar dan sering kali gagal karena hal tersebut.

Memperkenalkan teknologi dari luar memiliki resiko : kurang diterima secara sosial dan ekonomis oleh petani serta teknologi dengan menggunakan spesies dari luar bias jadi secara ekologis kurang sesuai misalnya penanaman lamtoro pada tanah masam. Uji coba dalam skala terbatas di Iahan petani untuk menguji ketepatgunaan suatu teknologi perlu dilakukan dan dievaluasi dengan baik sebelum teknologi tersebut dianjurkan untuk digunakan secara luas.

\section{Sistem - sistem Wana Tani Di Indonesia}

Sistem wana tani tradisional dapat ditemui di seluruh Indonesia antara lain sistem kebun talun dan pekaiangan di Jawa serta kebun - kebun berstrata banyak di Sumatrera. Sistem wana tani yang diintroduksi juga umum terdapat banyak di daerah dan sistem tersebut sering dipadukan dalam program pengembangan hutan pada Iahan hutan, disamping diterapkan pada Iahan - Iahan pertanian milik perorangan.

\section{Sistem Wana Tani Kebun}

\section{Sistem pekarangan}

Sistem wana tani pekarangan merupakan campuran antara tanaman umur panjang, tanaman semusim dan ternak (termasuk sapi) di pekarangan sekitar rumah berupa suatu sistem terpadu dengan batas - batas jelas yang memenuhi fungsi - fungsi ekonomis, biofisik dan sosiocultural. Sistem pekarangan berasal dari Jawa Tengah dan menyebar ke Jawa Barat dan Timur pada pertengahan abad ke-18.

Kebun talun dan kebun pekarangan di Jawa Barat memberikan penghasilan yang relatif baik serta juga sebagai sumber kalsium, vitamin A dan $\mathrm{C}$ yang baik.

Pada umumnya suatu pekarangan mempunyai struktur yang sama dari tahun ke tahun walaupun terkadang ada variasi pada tanaman musiman. Dua lapisan yang paling rendah (sampai ketinggian $2 \mathrm{~m}$ ) didominasi oleh umbi - umbian, sayur mayur dan bumbu - bumbu. Ubi kayu dan ganyong (Canna edulis) merupakan tanaman yang paling umum di pekaranagan.

Lapisan berikutnya (dari 2 - 5 m) didominasi oleh pisang, pepaya dan pohon buah buahan yang lain. Lapisan ke tiga (5 - $10 \mathrm{~m}$ ) didominasi oleh tanaman buah dan tanaman perdagangan seperti cengkeh, sedangkan lapisan tertinggi didominasi oleh kelapa dan tanaman tanaman lain seperti sengon (Albizin falcataria) sebagai kayu bangunan dan kayu bakar.

\section{Sistem kebun talun}

Sistem kebun talun biasanya terdiri dari tiga tahap : kebun, kebun campuran dan talun. Tahap pertama; kebun tetjadi apabila petani membuka hutan dan memulai menanam tanaman tahunan. Tanaman - tanaman ini biasanya dikonsumsi sendiri oleh keluarga petani dan hanya sebagian yang dijual sebagai sumber penghasilan. Pada tahap kebun ini terdapat tiga lapisan dasar, tanaman tahunan yang mendominasi : lapisan terendah terdiri atas tanaman rambat yang menutupi tanah dan hidup diketinggian $30 \mathrm{~cm}$. Lapisan dengan ketinggian $50-100 \mathrm{~cm}$ diisi oleh sayur - mayur dan bagian atas lapisan ini diisi 
dengan tanaman jagung, tembakau, ubi kayu dan tanaman - tanaman legum yang merambat dan diberi ajir.

Setelah dua tahun, anakan pohon mulai tumbuh dan secara bertahap mengurangi tempat untuk tanaman tahunan. Kebun secara bertahap menjadi kebun campuran dimana tanaman tahunan tumbuh diantara tanaman umur panjang yang belum dewasa. Nilai ekonomis kebun campuran tidaklah setinggi kebun, tetapi nilai biofisiknya meningkat. Sifat kebun campuran yang terdiversifikasi juga meningkatkan konservasi tanah dan air. Dalam sistem talun erosi sangat sedikit karena semak - semak dan guguran daun sangat melimpah. Jika semak semak dan guguran daun dikurangi maka erosi akan meningkat secara nyata.

Dalam kebun campuran tanaman tanaman yang tahan naungan seperti talas mcnempati ruling dibawah $100 \mathrm{~cm}$. ubi kayu merupakan lapisan kedua dari 1 - $2 \mathrm{~m}$ dan lapisan ketiga ditempati oleh pisang dan pepohonan.

Setelah memanen tanaman tahunan di kebun campuran, lahannya mungkin ditinggalkan selama dua sampai tiga tahun sampai didominasi oleh tanaman umur panjang. Tahapan ini dikenal sebagai tahapan talun dan merupakan puncak perkembangan sistem kebun talun.

Talun didominasi oleh campuran pohon pohon umur panjang dan bambu yang membentuk tiga lapisan tegak. Pada tahapan talun ini kebun dapat berupa berbagai bentuk seperti kebun kayu (untuk bahan bangunan dan kayu bakar), bambu dan campuran tanaman umur panjang.

\section{Sistem tiga strata}

Sistem tiga strata adalah metode penanaman dan pemanenan rerumputan, legum, semak dan pepohonan sedemikian rupa sehingga pakan ternak tersedia sepanjang tahun. Sistem ini dikembangkan oleh para petani di Bali. Lapisan pertama terdiri dari rerumputan dan tanaman legum, dimaksudkan untuk menghasilkan pakan pada musim hujan. Lapisan kedua terdiri dari semak yang dimaksudkan untuk penyediaan pakan pada pertengahan dan akhir musim hujan. Lapisan ke tiga terdiri dari pepohonan yang dimaksudkan untuk penyediaan pakan pada musim kemarau.

Sistem tiga strata membagi suatu lahan menjadi tiga bagian yaitu inti, selimut dan batas. Inti dipelihara untuk produksi pangan, areal dibagi menjadi beberapa bagian dan masing inasing bagian ditanami dengan beberapa jenis rumput dan legum. Pohon - pohon penghasil pakan ditanam disekitar batas dengan jarak 2 pohon setiap $5 \mathrm{~m}$. Di antara pohon - pohon ini lamtoro atau gamal (Gliricidia sepiuni) ditanam sebagai semak dengan jarak tanam $10 \mathrm{~cm}$. Tingkat pemeliharaan hewan sangat bervariasi dari yang sangat rendah $(0,5$ ha untuk setiap ekor sapi) sampai sangat tinggi $(0,25$ ha untuk setiap ekor sapi) karena ketersediaan pakan yang meningkat. Sapi yang dipelihara pada system ini tumbuh dengan cepat dan siap dipasarkan pada umur muda.

\section{Sistem ladang berpindah}

Sistem ladang berpindah atau disebut juga sistem tebas - bakar dipraktekkan secara luas hampir diseluruh pulau di Indonesia dengan perkecualian pulau Jawa. Sistem ladang berpindah mencakup beranekaragam tindakan yang dilakukan dibanyak lingkungan yang berbeda dalam keadaan yang berbeda pula.

Di Apo Kayan ( Kalimantan Timur), hampir semua hutan yang ditebas untuk lahan pertanian adalah hutan sekunder dan masa bera berkisar antara 10 - 30 tahun. Para petani berkeyakinan bahwa masa bera haras cukup panjang untuk mengurangi tanaman pengganggu dan untuk mencegah degradasi jangka pendek hutan menjadi semak belukar. Kadang kala ada tempat - tempat yang ditinggalkan untuk masa yang lebih lama lagi (40 - 50 tahun) untuk mencegah pengurangan kesuburan secara bertahap serta peningkatan jenis - janis tanaman pengganggu. Para petani mengakui keuntungan keuntungan sistem ladang berpindah dengan masa bera yang panjang.

Di Long Segar (Kalimantan Timur) para peladang berpindah lebih banyak menebang hutan primer dari pada hutan sekunder untuk lahannya. Masyarakat setempat menanam padi dan dengan mudah menjual kelebihannya melalui kapal kapal pedagang atau pasar lokal, hutan yang dibuka-dan diolah oleh para petani rata - rata 0,4 ha perkapita per tahun atau sekitar 33\% lebih besar dari pada di Apo Kayan. Luas daerah yang diolah pada tahun 1979 - 1980 sekitar 400 ha dan $82 \%$ diantaranya berasal dari hutan primer. Karena pasar, teknologi dan tekanan penduduk, diuir ulang ladang berpindah ini makin lama makin pendek. Karena pemulihan lahan kembali menjadi hutan sangat lambat, maka daur yang makin pendek akan mengakibatkan bahaya kerusakan lingkungan.

Menurut penelitian Colter (1992) tentang sistem ladang berpindah di Kalimantan Timur, menunjukkan bahwa ada beberapa kepercayaan tentang sistem ladang berpindah yang tidak dapat disama ratakan jenisnya dan tergantung pada setiap keadaan. 


\section{Sistem bera yang disempurnakan}

Teknologi bera yang disempurnakan merupakan salah satu alternatif untuk mengendalikan kebiasaan - kebiasaan ladang berpindah yang merusak dan mengembangkan sistem pertanian lahan kering yang berkeianjutan. Lahan - lahan yang ditinggalkan ditanami dengan tanaman penutup tanah yang tumbuh cepat seperti Peuraria javanica untuk memulihkan kesuburan tanah dan sebagai tanaman perdagangan umur panjang. Tanaman pangan dapat ditanam lagi setelah 3-4 tahun dalam satu masa bera yang jauh lebih singkat dari cara tradisional.

Pola tanam yang diperbaharui ini akan menghasilkan padi dan ubi kayu dalam waktu yang singkat, jahe dan kacang tanah dalam masa pendek, serta melinjo (Gnetum gnenion) dalam jangka panjang.

\section{Sistem kebun vana tani berstrata banyak di Sumatera Barat}

Ciri utama sistem ini adalah suatu keterpaduan yang intensif antara jenis - jenis tanaman hutan dan tanaman perdagangan dengan strata berlapis - lapis. Hubungan yang erat antara berbagai jenis tanaman untuk memperoleh hasil - hasil untuk kebutuhan petani sendiri, dijual ataupun melengkapi produksi padi.

\section{SIMPULAN}

Dari beberapa uraian di atas maka dapat disimpulkan beberapa hal sebagai berikut : (1) Agar dapat bekerja dengan para petani secara efektif dalam kegiatan wana tani, peneliti dan para pekerja pengembangan masyarakat harus mampu mendekati wana tani dari perspektif sistem usaha tani. (2) Manfaat langsung yang didapat melalui wana tani adalah manfaat jangka panjang yaitu peningkatan produktivitas tanah dan tanaman yang makin tinggi, perbaikan gizi masyarakat, perbaikan sosial ekonomi, tata guna lahan yang lebih mantam dan konservasi lingkungan. (3) Bila dilaksanakan secara baik, sistem - sistem wana tani dapat merupakan sarana yang efektif untuk merehabilitasi dan mengelola lahan kritis.

\section{DAFTAR PUSTAKA}

Atang, S. 1998. Sistem Agroforestry; Suatu Alternatif dalam Upaya Peningkatan Produktivitas Lahan. Badan Penyuluh Kehutanan. Jakarta

Bermanakusuma, R. 1978. Konservasi Tanah dan Air. IPB. Bogor

Direktorat Perluasan Areal. 1985. Cara - cara Konservasi Lahan. Dirjentan. Jakarta

Fitriadi, R. 1994. Partisipasi Petani dalam Pengembangan Plot dan Demplot Agroforestry. Pusat Penelitian dan Pengembangan Hutan dan Konservasi Alam (P3HKA) dan Asia Pasifik Agroforestry Network (APAN). Bogor

Nair, P.K.R. 1989. Classification of Agroforestry System. Dalam Agroforestry : Classification ang Management. Jhon Willey and Sons. New York

Perum Perhutani. 1990. Pedoman Agroforestry dalam Program Perhutanan Sosial, PHT. Seri 39. Perum Perhutani. Jakarta

Raintree, J.B. 1989. Theory and Practice of Agroforestry Diagnosis and Design International Council for Research in Agroforestry. Nairobi. Kenya

Suripin. 2001. Pelestarian Sumberdaya Tanah dan Air. Indi Offcet. Yogyakarta

Young, A. 1984. Land Evacuation of Agroforestry Potencial in Sloping Areas. Working Paper. Nairobi. Kenya 